\section{Um Tostão e um Dadá}

\section{Mário Alex Rosa}

A revista FuLiA/UFMG apresenta um par de poemas inédito, "Um Tostão e um Dadá", de Mário Alex Rosa, sobre dois ícones do futebol brasileiro, em que reverberam as possibilidades semânticas e plásticas das palavras "tostão" e "dadá".

Mário Alex Rosa é formado em História pela UFOP, mestre e doutor em Literatura Brasileira pela USP. Foi curador do FELIT (Festival de literatura de São João del-Rei). Atuou como Coordenador de Biblioteca e literatura no SESC/MG. É professor de Literatura Brasileira e poeta, autor dos livros Ouro Preto (Scriptum, 2012), Via Férrea (Cosac Naify, 2013), Poemas Pitorescos (Galileu Edições, 2020), Casa (Impressões de Minas, 2020) e Diário de Casa (Galileu Edições, 2021), além dos livros infantis $A B C$ Futebol Clube (Aletria, 2015) e Formigas (Cosac Naify, 2013). E coorganizador das antologias Pelada poética (Scriptum, 2013 e 2014).

\section{Um Tostão}

Dizem que um tostão não vale nada,

na mão de rico ou pobre

é cobre à toa.

Mas se esse tostão

é o cobra criada das pernas, esse sim vale o quanto passa: entre tantas outras pernas direita, esquerda, fina ou grossa, pouco importa.

O que é acaso vira lance, o que é lance por acaso tem sempre alcance, da esquerda, a mais precisa para a direita, a mais indecisa, sempre o direito de aprimorar-se (ninguém é perfeito)

para amordaçar o adversário.

Um tostão furado

é dito popular,

mas um tostão com a bola

é ouro lapidado. 
DADÁ

UMA

DÁDIVA

UM

SOYANIIO

DA

VIDA

QUANDO

ÍA

DO

Có́u

À

TRRRA

BBIJUA-FIOR

(QUE

VIA

HÍ́LCE

NA

cabreça

QUE

GIRA

TRẾS

MARAVIUHAS

NA
BS

A

NA

ÁRDA

CHIIA

TU

FA

(

I

T

(1)

D $\mathbf{E}$

ç

(1)

DA

U

$\mathbf{N}$

c

$\mathbf{E}$

D $\mathbf{E}$

D

A
(D

ILHA 